\title{
BORGES Y EL CIVILIZADO ARTE DE LA TRADUCGIÓN: UNA INFIDELIDAD CREADORA Y FELIZ
}

A mis ex alumnos del PFT*

El error consiste en que no se tiene en cuenta que cada idioma es un modo de sentir el universo o de percibir el universo

"Las versiones homéricas", ensayo de Jorge Luis Borges incluido en Discusión, empieza con una frase lacónica y enfática: "Ningún problema tan consustancial con las letras y con su modesto misterio como el que propone una traducción"l. Cuando escribió esta sentencia (por cierto tan sugestiva que Georges Steiner decidió usarla como uno de los epígrafes de su libro Después de Babel ${ }^{2}$ ), Borges llevaba más de un decenio de ejercer el oficio de traductor. En efecto, a partir de 1920 las efímeras revistas españolas donde se difundió el ultraísmo recibieron la contribución del joven escritor argentino, quien publicó en ellas tanto sus primeros textos como traducciones de poemas recientes del inglés, el alemán y el francés ${ }^{3}$; más allá de las pro-

* Una mucho más breve versión preliminar de este trabajo, con el título "Borges: traducciones y versiones", fue leída durante el XXXIII Congreso del Instituto de Literatura Iberoamericana, en junio de 2000 en Salamanca.

1 "Las versiones homéricas", Discusión (1932), en Obras completas, Emecé, Buenos Aires, 1996, t. 1, p. 239. Este texto apareció por vez primera el 8 de mayo de 1932 en el diario La Prensa.

2 Después de Babel. Aspectos del lenguaje y la traducción, trad. Adolfo Castañón, F. C. E., México, 1980.

${ }^{3}$ De hecho, la carrera literia de Borges se inicia en revistas ultraístas es- 
bables virtudes de estas versiones traducidas, se puede reconocer en ellas a un autor en busca de su voz poética, pues como señala Gallego Roca: "Borges desliga la práctica de la traducción poética del proyecto colectivo que implica toda revista, y si bien toma partido por los criterios ultraístas desde la prosa crítica, sus traducciones son los tanteos del poeta que recurre a la imitatio en busca de unos sólidos criterios personales"4.

Quizá en algunos casos, los rasgos específicos de estas versiones se deban tanto a la búsqueda personal de Borges como a sus dudosas capacidades verbales para manejar otra lengua; por ejemplo, luego de comparar una de esas traducciones con su original en alemán, un crítico concluye que el incipiente escritor o bien no tenía un conocimiento profundo de ese idioma o bien traducía con bastante libertad ${ }^{5}$; este juicio no debe sorprender, pues, en primer lugar, era imposible que Borges tuviera conocimientos excelsos y semejantes de las diversas lenguas de las que tradujo en 1920; además, él mismo fue siempre escéptico respecto de sus capacidades verbales en alemán.

En fin, aunque no me propongo examinar las versiones de poemas de esas tres lenguas preparadas entonces por el autor (tema que, por otra parte, está fuera de mis límites), menciono esta faceta inicial suya como una muestra de su interés primigenio por la traducción, aspecto al cual dedicó múltiples reflexiones en sus ensayos y que incluso forma parte sustancial de algunas de sus ficciones; por ello puede decirse, sin miedo a incurrir en hipérboles, que hablar de la traducción en Borges implica aludir a toda su literatura; porque ¿̇acaso no comenzó él su carrera literaria en plena infancia con una traducción de "El príncipe feliz" de Oscar Wilde? 6

pañolas, donde publica, entre otros: "Lírica inglesa actual" ( Grecia, 20 de febrero de 1920, núm. 40, p. 8); "Novísima lírica francesa" (Grecia, 29 de febrero de 1920, núm. 41, 15-16); "Lírica austriaca de hoy" (Grecia, 20 de marzo de 1920, núm. 42, p. 11); "Lírica expresionista [Heynicke y Klemm]" (Grecia, 1 de agosto de 1920, núm. 47, 10-11); "Lírica expresionista [Klemm]" (Grecia, 1 de noviembre de 1920, núm. 50, 10-11); "Antología expresionista" (Cervantes, octubre de 1920, 100-112).

${ }^{4}$ Poesía importada. Traducción poética y renovación literaria en España (19091936), Universidad, Almería, 1996, p. 197. (Estas primeras traducciones borgeanas se describen en las pp. 197-207.)

${ }^{5}$ Véase José Luis VeGA, “"Der Aufbruch» / «El arranque»: un ejemplo de las traducciones expresionistas de Jorge Luis Borges”, Sendebar (Granada), 5 (1994), 241-248.

6 OSCAR WILDE, "El príncipe feliz”, traducido del inglés por Jorge Borges 
$\mathrm{Al}$ igual que sucedió con otros temas relacionados con el arte verbal, al escritor argentino no le interesó postular una teoría total o un pensamiento sistemático sobre la traducción, sino más bien usarla pragmáticamente, ya que creía que en ella resultaban visibles los variados procedimientos de la construcción literaria, como se deduce de esta frase: "La traducción... parece destinada a ilustrar la discusión estética" 7 . Por lo tanto, conviene citar el pertinente punto de partida de Sergio Pastormerlo, que habrá de asumirse como una prevención en este trabajo:

En realidad, Borges opta precisamente por la dirección contraria a la que elegiría un teórico de la traducción: en lugar de usar ciertas reflexiones sobre la literatura, toma como punto de partida las traducciones para elaborar ciertas reflexiones sobre la literatura: la negación del autor, la lectura, las creencias y las valoraciones literarias ${ }^{8}$.

Ahora bien, el primer acercamiento reflexivo de Borges al tema fue "Las dos maneras de traducir" (1926), que con su estilo típico del período marcó desde el arranque cierta distancia respecto de ideas comunes: "Suele presuponerse que cualquier texto original es incorregible de puro bueno, y que los traductores son unos chapuceros irreparables, padres del frangollo y la mentira. Se les infiere la sentencia italiana de traduttore traditore y ese chiste basta para condenarlos" ${ }^{9}$. En este ensayo está el germen de una idea que asumirá variadas enunciaciones posteriores: las dos formas generales de traducir, es decir la que intenta reproducir todos los detalles verbales del original y la que prescinde de ellos para mantener el significado global, remiten a los grandes modelos de la literatura: "Universalmente, supongo que hay dos clases de traducciones. Una practica la literalidad,

(hijo), El País, 25 de junio de 1910, p. 3.

7 J. L. Borges, "Las versiones homéricas", p. 239.

8 "Borges y la traducción", Borges Studies on Line, Borges Center for Studies and Documentation. Internet: 02/10/99 (http:/www.hum.au.dk/romansk/borges/bsol/pastorm1.htm).

${ }^{9}$ En Textos recobrados, 1919-1929, Emecé, Buenos Aires, 1997, p. 256. [Este ensayo fue publicado originalmente en La Prensa el 1 de agosto de 1926]. Hay que decir, de paso, que el joven Borges no fue ajeno a la costumbre de demeritar la labor traductora, pues en "Acerca del expresionismo" (Inicial, núm. 3, diciembre de 1923) justificó sus traducciones con esta tímida frase: "El culpable de haber castellanizado estos versos, soy yo". 
la otra la perífrasis. La primera corresponde a las mentalidades románticas, la segunda a las clásicas"10; por cierto que en la asimilación de la actividad traductora a dos arquetipos, el romántico y el clásico, puede percibirse también ese particular "neoplatonismo" que cruza toda la obra borgeana y que ha sido descrito por Juan Nuño ${ }^{11}$.

Asimismo, en un obvio adelanto de lo que desarrollará años después en su clásico ensayo "El escritor argentino y la tradición", Borges asume una postura escéptica respecto de los traductores que desean mantener a toda costa las singularidades del original que pudieron haber sorprendido a sus primeros receptores: "El anunciado propósito de veracidad hace del traductor un falsario, pues éste, para mantener la extrañeza de lo que traduce, se ve obligado a espesar el color local, a encrudecer las crudezas, a empalagar con las dulzuras y a enfatizarlo todo hasta la mentira"12. Al final de "Las dos maneras de traducir", el aventurero Borges propone realizar el juego de la traducción dentro del mismo idioma:

Es sabido que el Martín Fierro empieza con estas rituales palabras: "Aquí me pongo a cantar- al compás de la vigüela". Traduzcamos con prolija literalidad: "En el mismo lugar donde me encuentro, estoy empezando a cantar con guitarra", y con altisonante perífrasis: "Aquí, en la fraternidad de mi guitarra, empiezo a cantar", y armemos luego una documentada polémica para averiguar cuál de las dos versiones es peor. La primera, ¡tan ridícula y cachacienta!, es casi literal ${ }^{13}$.

Sin duda, los ejemplos inventados por él son hiperbólicos y tendenciosos, pero sirven para demostrar que desde el principio sus prevenciones mayores se aplicaron a los seguidores de las versiones literales.

${ }^{10} \mathrm{~J}$. L. Borges, "Las dos maneras de traducir", pp. 257-258.

${ }^{11}$ Cf. La filosofía de Borges, F.C.E., México, 1986.

12 "Las dos maneras de traducir", p. 258.

13 Ibid., p. 259. Varios decenios después, Borges usa un contraejemplo semejante para exponer la misma idea: "Imaginemos una traducción literal de un verso de Darío: «La princesa está pálida en su silla de oro» es literalmente igual a «En su silla de oro está pálida la princesa». En el primer caso el verso es muy lindo ¿no?, por lo menos para los fines musicales que él busca. Su traducción literal, en cambio, no es nada" ("El oficio de traducir", en Borges en "Sur", 1931-1980, Emecé, Buenos Aires, 1999, pp. 321-322. [Originalmente en Sur, ene-dic. de 1976, núms. 338-339, y antes en La Opinión Cultural, 21 de sept. de 1975]). 
Durante la década de 1930, Borges escribe dos ensayos sobre el tema que, mutatis mutandis, coinciden en sus líneas generales: el breve y citado "Las versiones homéricas" y el largo pero magistral "Los traductores de Las 1001 noches"14, cuya prosa destaca por su alto grado de concentración poética y su manejo de la ironía. En principio, los fundamentos de "Las versiones homéricas" pueden parecer paradójicos, pues simulan una alabanza a la ignorancia:

El Quijote, debido a mi ejercicio congénito del español, es un monumento uniforme, sin otras variaciones que las deparadas por el editor, el encuadernador y el cajista; la Odisea, gracias a mi oportuno desconocimiento del griego, es una librería internacional de obras en prosa y verso, desde los pareados de Chapman hasta la Autorized Version de Andrew Lang o el drama clásico francés de Bérard o la saga vigorosa de Morris o la irónica novela inglesa de Samuel Butler ${ }^{15}$.

Las implicaciones de la frase "oportuno desconocimiento del griego", que yo defino como una especie de oxímoron (¿acaso puede ser "oportuna" la ignorancia?), son altamente productivas para la literatura, pues el receptor que ignora la lengua original de un texto no está sujeto a éste por convicciones atávicas. En este sentido, resulta lógico que la tarea de análisis de las traducciones de Homero al inglés se ejerza prescindiendo de compulsarlas con el original en griego. Pero además de ello, en el ensayo se practica aquello que se desea juzgar, pues en su cotejo y transcripción del mismo pasaje homérico de Buckley, Butcher-Lang, Cowper, Pope, Chapman y Butler, Borges no ofrece al lector la versión "original" en inglés, sino su traslación al español; de este modo, los adjetivos con que se califican las supuestas versiones en inglés (literal, arcaizante, inocua, extraordinaria, oratoria, visual, calmosa), deberían aplicarse, en última instancia, a la versión españolizada, cuyas diferencias o simpatías con la versión previa ignora el lector. Enfatizo este punto, porque si bien algunos críticos señalan que Borges no sabía griego (o árabe, en el caso de "Los

${ }^{14} \mathrm{Al}$ igual que solía hacer su gran amigo Alfonso Reyes, en este texto Borges funde y extiende dos ensayos previos: "El puntual Mardrus" y "Las 1001 noches", ambos en Revista Multicolor de los Sábados, 3 de febrero de 1934, p. 8, y 10 de marzo de 1934, p. 5, respectivamente.

15 "Las versiones homéricas", p. 240. 
traductores de Las 1001 noches"), se olvidan de añadir que tampoco copió las versiones en lengua inglesa, las cuales más bien fueron sustituidas por traducciones al español preparadas ex profeso; esta costumbre no sonará ajena a quien conozca la obra inicial del autor, cuando citaba en español textos provenientes de lenguas extranjeras (desde el inglés hasta el alemán, pasando incluso por el latín), sin asumir la paternidad de la traducción ${ }^{16}$. Encuentro un motivo para esta hábil omisión: si se explicitara el acto de mediación, se prevendría al receptor, quien sería consciente de no poseer el texto "original" sino tan sólo un sustituto de éste; sospecho que el efecto es familiar para todos, pues con frecuencia (por ejemplo, en la lectura de la novela rusa) prestamos nuestra fe ciega al texto traducido, sin reparar en que se trata de una mediación muy compleja.

En suma, el lector de "Las versiones homéricas" no recibe ni el original en griego (que seguramente desconocería), ni sus versiones en inglés, sino tan sólo las traducciones al español formuladas por el ensayista. Para poder evaluar todo el conjunto, el lector ideal del ensayo necesitaría, en un proceso que, como un juego entre dos espejos, se remonta al infinito, la versión "original" en griego, sus traducciones al inglés y, por último, las traducciones de éstas al español; además, claro está, ese lector ideal tendría que poseer enormes competencias lingüísticas. En su estrategia expositiva, Borges olvida estas complicaciones y procede como si hubiera citado las versiones en lengua inglesa, respecto de las cuales se pregunta y responde:

16 Uno de los esporádicos pasajes donde se indica que se trata de una traducción es "La nadería de la personalidad": "Traslado el tal lugar [de Schopenhauer] que, castellanizado, dice así:" (Inquisiciones [1925], Seix Barral, Buenos Aires, 1994, p. 102). AnNick Lous propone diferenciar entre los términos "castellanizar" y "españolizar", también usado por el autor en el período: "Cierta distancia existe entre los dos términos: «castellanizar» significa más bien dar forma española a algo en otro idioma, mientras que «españolizar» no designa originariamente un problema de lengua, sino el hecho de comunicar las costumbres españolas. Si el primero reenvía a la traducción al castellano, el segundo implica una nueva dimensión: la «españolización de los versos» acarrea la inscripción de lo español en un objeto o una persona, y por extensión, en una lengua perteneciente a una cultura o a una lengua diferentes. En otras palabras, no se trata de proponer un equivalente en la propia lengua de aquello expresado en una lengua extranjera, sino de inscribir la propia lengua en lo extranjero" (Jorge Luis Borges: Quvre et manœuvres, L'Harmatan, Paris, 1997, p. 303; agradezco a la autora el haberme proporcionado la traducción al español de su libro). 
¿Cuál de las muchas traducciones es fiel?, querrá saber tal vez mi lector. Repito que ninguna o que todas. Si la fidelidad tiene que ser a las imaginaciones de Homero, a los irrecuperables hombres y días que él representó, ninguna puede serlo para nosotros; todas, para un griego del siglo diez. Si a los propósitos que tuvo, cualquiera de las muchas que transcribí, salvo las literales, que sacan toda su virtud del contraste con hábitos presentes. No es imposible que la versión calmosa de Butler sea la más fiel ${ }^{17}$.

Así, de forma maestra se retoma un criterio, el de la fidelidad al original, que de hecho el ensayo había derruido, y se plantea también algo imposible de discernir, por lo menos con los elementos proporcionados: que la versión de Butler sea la más cercana al texto griego. Aunque Borges finge preguntarse por la "fidelidad" de una traducción respecto de una presunta obra "original", es obvio que el eje de la discusión se ubica más bien en la eficacia con que pueda ser recibido o descodificado un texto, sea éste un "original" o una mera versión traducida; así llega él a proponer lo que parecerá una herejía a los dogmáticos que cifran su fe en la eventualidad de una traducción definitiva, única y perfecta: no se debe rechazar ninguna de las versiones homéricas, pues todas tienen posibilidades múltiples de lectura, pueden hacer resonar en el receptor ecos de las ignoradas intenciones originales del autor. Con base en estas ideas borgeanas, Efraín Kristal concluye pertinentemente:

Para determinar la fidelidad de una traducción se debe, sin duda, conocer el original. Pero no es necesario conocer el original para determinar el valor estético de una traducción... Optar por una traducción literal o por una recreación de un texto es una decisión estética. En principio, ambas pueden ser igualmente legítimas. El criterio principal con el que Borges evalúa una traducción es su mérito literario y no su fidelidad al original ${ }^{18}$.

En este punto, y con el objeto de superar la falsa dicotomía entre traducción "literal" y traducción "literaria", convendría preguntarse de qué depende esa decisión estética que inclina la voluntad del traductor hacia uno u otro polo intencional. Para ello, enlazaré las ideas de Borges con una de las más modernas teorías sobre la traducción; creo que el contraste servirá

17 "Las versiones homéricas", p. 243.

18 "Borges y la traducción”, Lexis, 23 (1999), p. 8. 
para evaluar en su correcta perspectiva las geniales intuiciones sobre el tema que tuvo el escritor argentino. En esto me ayudaré parcialmente del libro del alemán Hans Josef Vermeer titulado Skizzen zu einer Geschichte der Translation, que podría traducirse como Bosquejos para una historia de la translación, accesible para mí gracias a su traducción parcial al español ${ }^{19}$.

Vermeer, especialista en literatura grecolatina, se interesa en el tema no sólo como traductor de textos clásicos, sino porque la preocupación sobre esa práctica está en uno de sus autores favoritos: Cicerón, quien en De optimo genere oratorum escribió:

Traduje, pues, esos conocidísimos discursos, contrarios entre sí, de Esquines y Demóstenes, dos oradores de los más elocuentes entre los áticos; pero no los traduje como intérprete, sino como orador: con sus mismos pensamientos tanto en las imágenes como en las figuras, con palabras aptas a nuestro uso verbal. En ellos no tuve necesidad de traducir palabra por palabra; más bien les conservé a éstos todo su origen y su fuerza ${ }^{20}$.

"Con palabras aptas a nuestro uso verbal", dice Cicerón; a partir de éste y de otros fragmentos del mismo texto, Vermeer concluye que el latino traducía con un objetivo específico en mente; a esto es a lo que el teórico llama Skopostheorie o Teoría del skopos, cuyo criterio general para la actividad translatoria es pensar que todo texto debe redactarse y funcionar para un uso; se trata de una teoría de la traducción estrictamente funcional, que considera que ésta debe hacerse con un objetivo, dentro de la cultura a la que pertenece la lengua de llegada y para unos destinatarios bien precisos. Este fin tiene que cumplirse óptimamente a partir de un conocimiento profundo del texto original, pero para ello siempre será preciso que cambie el texto de partida; de acuerdo con los consejos de la retórica clásica, al hablar (y al traducir), hay que saber cuál es o era el quis, el quid, el ubi, el quibus auxiliis, el cur, el quomodo, el quando del que escribió dicho texto, y cuáles las circunstancias de aquéllos para quienes iba dirigidos; pero como desde el presente todo

${ }^{19}$ En Cicerón y la translatología según Hans Josef Vermeer, UNAM, México, 1996, Pedro C. Tapia Zúniga ha hecho un singular y aprovechable ejercicio: la traducción y comentario de varios capítulos de la obra de Vermeer.

${ }^{20}$ Cicerón apud P. C. TAPIA ZÚÑIGA, Cicerón y la translatología según Hans Josef Vermeer, p. 90 (trad. de Cicerón hecha por José Quiñones Melgoza). 
ha cambiado, es decir todas las circunstancias son distintas, la traducción tiene que ser un texto nuevo, distinto del original.

Según esta teoría, no puede existir una traducción pura y "literal", puesto que el traductor nunca logrará recuperar todas las particularidades de emisión o producción del texto; hay una gran semejanza entre este concepto y la siguiente afirmación del escritor argentino donde la discusión entre John Henry Newman y Matthew Arnold sobre la traducción de Homero ${ }^{21}$ es citada para rechazar que ambos polos de la traducción puedan cumplirse a la letra:

La hermosa discusión Newman-Arnold (1861-62), más memorable que sus dos interlocutores, ha razonado extensamente las dos maneras generales de traducir. Newman vindicó en ella el modo literal, la retención de todas las singularidades verbales; Arnold, la severa eliminación de los detalles que distraen o detienen. Esta conducta puede suministrar los agrados de la uniformidad y la gravedad; aquélla, de los continuos y pequeños asombros. Ambas son menos importantes que el traductor y que sus hábitos literarios. Traducir el espíritu es una intención tan enorme y tan fantasmal que bien puede quedar como inofensiva; traducir la letra, una precisión tan extravagante que no hay riesgo de que la ensayen ${ }^{22}$.

Y si acaso alguien se atreve a ensayar ingenuamente esa traslación "literal", los resultados no serán positivos, como se aprecia en su juicio de la traducción al alemán de Las 1001 noches preparada por Littmann, contra quien Borges ejerce esa ironía que está en los orígenes de su escritura y que se afinó con el paso del tiempo hasta alcanzar su apogeo en la década de 1930: "[Littmann] Es siempre lúcido, legible, mediocre. Sigue (nos dicen) la respiración misma del árabe. Si no hay error en la Enciclopedia Británica, su traducción es la mejor de cuantas circulan. Oigo que los arabistas están de acuerdo; nada importa que un mero literato - y ése, de la República meramente Argentina- prefiera disentir" 23 .

Por otra parte, es obvio que en los dos ensayos analizados, Borges alude, en mayor o menor grado, al skopos de las diversas

${ }^{21}$ Un buen resumen de la famosa polémica Newman-Arnold se encuentra en EFraín Kristal, art. cit., pp. 4-6.

22 J. L. Borges, "Los traductores de las 1001 noches", Historia de la eternidad, en Obras completas, ed. cit., t. 1, p. 400.

23 Ibid., p. 411. 
traducciones de Homero y Las 1001 noches, pues por medio de la distinción de los rasgos de cada texto, intenta definir cuál fue el objetivo que el traductor tuvo en mente y a qué público se dirigía, como plantea respecto de la tan gustada por él versión de Richard Francis Burton de la obra clásica de origen árabe24: "Queda el problema fundamental [de Burton]. ¿Cómo divertir a los caballeros del siglo diecinueve con las novelas por entregas del siglo trece?"25

Para definir dónde se ubica la labor del traductor y cuáles pueden ser sus alcances, cabe citar la opinión de Borges sobre Néstor Ibarra, cercano amigo suyo y también su traductor al francés:

Ibarra es un caso muy raro. Tiene un gran talento literario. No sé qué modestia o qué ironía le impide escribir o publicar lo que ha escrito. Prefiere traducir. Quizá piensa que el oficio de traductor es más sutil, más civilizado que el del escritor: el traductor llega evidentemente después que el escritor. La traducción es una etapa más avanzada ${ }^{26}$.

En su aspecto individual, este comentario resulta singular, pues no sé si los elogios a Ibarra provengan del hecho de que éste, más que traducir, haya ejercido la recreación de la poesía de Borges, como se percibe con facilidad en uno de los cuartetos de "La luna", cuya lección en español dice:

${ }^{24}$ La apreciación de Borges sobre la calidad de la versión de Burton no andaba errada, a juzgar por lo que dice el autor de la más reciente y documentada biografía del erudito y aventurero inglés: "En manos de Burton se ha convertido en una traducción que no tiene parangón alguno, aun cuando otros hubiesen probado fortuna con otras tantas vertientes del árabe. Hay que decir que su texto no tiene rival, ya que alcanza una calidad poética soberbia. Las notas que completan los volúmenes bastarían por sí solas para garantizar la reputación de muchos otros hombres, y los ensayos que funcionan como epílogo, en los que Burton se ocupa de las condiciones sociales y religiosas en cuyo marco vieron la luz los cuentos de Las mily una noches, son obras maestras en su categoría” (EDward Rice, El capitán Richard F. Burton, trad. Miguel Martínez-Lage, Siruela, Madrid, 1999, p. 509).

25 J. L. Borges, "Los traductores de las 1001 noches", p. 405.

$26 \mathrm{~J}$. L. Borges apud Georges Charbonnier, El escritor y su obra, $3^{\mathrm{a}} \mathrm{ed}$., trad. Martí Soler, Siglo XXI, México, 1975, p. 12. 
Pitágoras con sangre (narra una

Tradición) escribía en un espejo

Y los hombres leían el reflejo

En aquel otro espejo que es la luna.

Por su parte, con el fin de conseguir una forma métrica rimada, Ibarra traslada al francés de la siguiente manera:

Pythagore écrivait avec du sang sur une

Plaque polie et, fait rarement contesté,

Ses disciples lisaient le texte reflété

Dans cet autre miroir qu'est la céleste lune.

Si no me equivoco, la frase "fait rarement contesté" esta ahí solamente para rimar con "reflété", del mismo modo que el adjetivo "céleste" nada más sirve para alcanzar el metro del verso (aunque quizá aquí Ibarra se apoye en un verso posterior que habla de la "celestial luna") ${ }^{27}$.

En fin, más allá de las generosas razones que Borges haya tenido para alabar hiperbólicamente a Ibarra ${ }^{28}$, lo sustancial es que, en el pasaje transcrito, de hecho él considera que el traductor está en la cima de la cadena de producción literaria. Quizá para comprender cabalmente qué significa esa etapa, convenga volver a Vermeer, quien al comentar un pasaje del Arte poética de Horacio, concluye: "Decir de nuevo lo que ya está

${ }^{27}$ En su muy útil edición anotada de Borges, de donde he tomado el texto, Jean Pierre Bernès justifica así conservar la versión al francés de este poema preparada por Ibarra: "On a conservé pour ce poème la flamboyante traduction d'Ibarra qui, avec constance, privilégie la richesse des rimes, quitte à opérer de singulières transformations, voire à introduire des noms propres étrangers au texte original" ( J. P. Bernès, en Jorge Luis Borges, (Euvres complètes, Gallimard, Paris, 1999, t. 2, p. 1161).

28 De hecho el criterio de la recreación es el que prima cuando Borges enjuicia las traducciones de sus textos: "Los han traducido muy bien. Salvo al alemán. Las traducciones al francés que han hecho Ibarra y Roger Caillois son muy buenas. Las de Di Giovanni al inglés también son buenas. Las traducciones de sonetos que hicieron él y otros poetas americanos son muy buenas porque los han recreado. Las traducciones de sonetos no pueden ser literales y conservar el sentido" ( J. L. BORGES, "El oficio de traducir", pp. 324-325). Aunque no solía hacerlo, excepcionalmente en este ensayo se queja de las falsas traducciones a sus textos, cuando menciona el caso de un cuento suyo donde la frase "llegaba un oscuro", referente al color de un caballo, fue trasladada al alemán como "llegaba el crepúsculo". 
dicho poéticamente es más difícil que poetizar por primera vez. Esto, aplicado a la traducción (a la cual Horacio no se refiere en este pasaje), significa lo siguiente: la traducción es un arte más difícil que el de escribir libremente, ya en prosa, ya en poesía"29. La traducción, entonces, como un "civilizado arte", como una etapa más avanzada, en palabras de Borges, o bien, según Vermeer, como un "arte más difícil que el de escribir libremente". No importa cuál de las dos postulaciones aceptemos, pues es claro que cualquiera de ellas nos lleva a conclusiones semejantes, entre otras la de destruir nuestra absurda convicción en la presunta inferioridad del traductor frente al "creador", amonedada en el cansino adagio italiano de "traduttore traditore" (respecto del cual, por cierto, Borges dice que no puede ser trasladado literalmente a ningún otro idioma, ya que siempre se pierde el ingenioso juego de palabras del italiano); Vermeer afirma incluso que en virtud de que el traductor se enfrenta a un texto producido por otro en circunstancias distintas, su proceso de reescritura se somete a más reglas y exige más competencias que las necesarias para escribir con absoluta libertad (si es que esto último existe, añado yo).

Me pregunto, por otra parte, si esta afirmación de Vermeer no coincide casi puntualmente con lo que Georges Steiner ha señalado con agudeza respecto de la ficción borgeana "Pierre Menard, autor del Quijote", cuyo protagonista emprende la asombrosa empresa de volver a escribir la obra de Cervantes y, por lo tanto, renuncia de antemano a la posibilidad de componer "libremente":

Menard asume el "misterioso deber" de recrear deliberada y explícitamente lo que en Cervantes fue un proceso espontáneo. Pero si bien Cervantes compuso libremente, la forma y la sustancia del Quijote poseían una naturalidad autóctona y, a decir verdad, una necesidad ahora desvanecida. De ahí una segunda e imperiosa dificultad para Menard: "Componer el Quijote a principios del siglo XVII era una empresa razonable, necesaria, acaso fatal; a principios del veinte, es casi imposible. No en vano han transcurrido trescientos años, cargados de complejísimos hechos. Entre ellos, para mencionar uno solo: el mismo Quijote". En otras palabras, cada acto genuino de traducción es, al menos en el corto sentido, un absurdo, un intento de remontar la escala del tiempo

${ }^{29}$ H. J. Vermeer en P. C. TAPIA ZÚÑIGA, op. cit., p. 52. 
y de recopiar voluntariamente lo que fue un movimiento espontáneo del espíritu. Con todo, "el fragmentario Quijote de Menard es más sutil que el de Cervantes”. Cómo no asombrarse de la habilidad de Menard para dar voz a sentimientos, pensamientos y consejas tan extraños a su época, para encontrar fórmulas perfectamente exactas para transmitir afectos notoriamente distintos de lo que él está acostumbrado a tener ${ }^{30}$.

Entro ahora, en este recorrido sobre la traducción, al aparentemente secundario campo de las anécdotas que forma ya parte del legado cultural de Borges, y del cual quiero rescatar aquí una significativa historia. Según un testimonio muy posterior de Roberto A. Tálice, cuando a inicios de los años treinta Borges comenzó a colaborar con Ulyses Petit de Murat en la codirección de la Revista Multicolor, suplemento del diario sensacionalista Crítica, pronunció, en un imprevisto acto frente a los miembros de la redacción, una "conferencia" sobre la traducción, que él recuerda así:

Amplia fue la disertación de Borges. Abundó en apreciaciones muy personales y justicieras sobre el valor de las traducciones y de los traductores y remató sus aleccionadoras palabras declarando que de ocupar él un cargo ministerial de Educación, instituiría una cátedra de traducción y si tuviera un cargo mayor, fundaría la Academia de Traductores... Ulyses Petit de Murat, libre de toda intención sarcástica, con la más creíble seriedad, aportó el colofón oral: "Al parecer, Borges concede más importancia a las traducciones que a sus creaciones literarias. No deja de ser expresión de sentida modestia" ${ }^{31}$.

${ }^{30}$ G. STEINER, op. cit., p. 93. Aunque esta idea me parece certera, coincido con AnNick Louis (op. cit.) en que el concepto de traducción de Steiner difiere del de Borges, pues mientras el primero alude a la miseria específica de la traducción y apoya la idea de que hay una interpretación verdadera y legítima del texto, para Borges, como hemos visto, no hay miseria sino riqueza de la traducción, basada en la diversidad de posibilidades creativas que implica la falta de sujeción a un texto inamovible. Me parece que desde el título de su obra, Después de Babel, Steiner postula un sentimiento de nostalgia absoluta por la pérdida de ese paraíso verbal que significaba una lengua única; por el contrario, para Borges el término Babel adquiere implícitamente un sentido simbólico positivo (como si dijera: "gracias quiero dar a la diversidad de las lenguas del mundo").

${ }^{31}$ Roberto A. TÁlice, "Elogio al traductor", incluido en Borges: obras, reseñas y traducciones inéditas, 2a ed., comp. Irma Zangara, Atlántida, Buenos Aires, 1999, p. 232. 
Por más hiperbólico que pueda sonar este relato, evidencia algo fundamental: que al desarrollar sus labores de difusión cultural, faceta de su obra poco estudiada, Borges fue muy consciente de la función desempeñada por las traducciones. Curiosamente, este rasgo lo acerca a sus adversarios estéticos del grupo Boedo, quienes impulsaban un proyecto cultural para el que la traducción resultaba una labor imprescindible, pues sólo con esa mediación podrían difundirse obras extranjeras entre amplios grupos sociales que ignoraban otras lenguas. Así, pese a sus diferencias de carácter estético e ideológico sobre cuál debería ser la finalidad última del arte, es obvio que tanto Borges como los miembros de Boedo comprendieron que el trabajo del traductor no era de ninguna manera secundario. En contra de la tradición decimonónica de la alta cultura rioplatense, desdeñosa de quien no leyera en la lengua original, Borges emprendió una carrera literaria que incluyó a la traducción como uno de sus centros. Aunque haya razonables dudas respecto de la autoría exclusivamente borgeana de algunas de sus traducciones, también en este ámbito su trabajo fue ingente ${ }^{32}$. Pero antes de referirme a esta parcela de su obra, quiero detenerme un poco en la forma como evaluaba el autor las traslaciones de una lengua a otra.

Atento desde la década de 1920 a juzgar diversas traducciones, sobre todo las de textos rioplatenses, en 1934 Borges dedicó un artículo de la Revista Multicolor de los Sábados a comentar una muy reciente traducción al inglés de Don Segundo Sombra, novela que se había convertido ya en una indisputada cúspide de la literatura argentina. Como se podría prever, recurre aquí

${ }^{32}$ En cuanto a las funciones de traductor de Borges, todavía nos movemos en un terreno incierto. Así, por ejemplo, en Borges: obras, reseñas y traducciones inéditas (op. cit.), se le adjudica la autoría de varios de los textos traducidos que se publicaron sin firma en la Revista Multicolor de los Sábados, pero no se proporciona ningún argumento para ello. Creo que sería necesario compulsar minuciosamente los originales con las traducciones anónimas para detectar si en éstas hay rasgos estilísticos borgeanos; mientras no se efectúe esta laboriosa tarea, convendría asumir la cauta actitud de sólo consignar las traducciones que sí fueron firmadas por el escritor; en última instancia, no es necesario abultar el índice de traducciones del autor; así, como mera muestra no exhaustiva, basta con señalar que en las décadas de 1930 y 1940 tradujo a autores tan diversos como André Gide, Virginia Woolf (dos libros), Henri Michaux, Herman Melville, William Faulkner, Francis Bret Harte, Thomas Carlyle y Ralph Emerson, amén de la traducción de $L a$ metamorfosis de Franz Kafka firmada por él pero más bien dudosa. 
al mismo método de "Las versiones homéricas", pues cita en español las palabras inglesas cuya pertinencia comenta. Al comparar la versión inglesa de esa obra con la francesa, el criterio borgeano se basa, más que en las habilidades del traductor, en las bondades inherentes a una lengua:

Es conocida la bondad de la versión francesa; ésta de Waldo Frank es muy superior. Ello se debe a que el idioma inglés es idioma imperial, vale decir, idioma que corresponde a casi todos los destinos humanos, a las maneras más diversas de ser un hombre. Hay una zona del inglés que puede superponerse con precisión al cansado español de los troperos de nuestro Ricardo Güiraldes. Hablo del inglés ecuestre de Montana, de Arizona o de Texas, madres de incomparables rider of horses - como dijo Whitman del gaucho. El patois de la versión francesa tiene algo de irreparablemente agrícola o chacarero, connota bueyes laboriosos y blusas, no altos jinetes y ríos colorados de toros. El traductor americano, inversamente, ha podido recurrir a un inglés que es bien de a caballo ${ }^{33}$.

Dejo de lado la curiosa coincidencia entre Borges y Antonio de Nebrija, quien en el riquísimo prólogo a su Gramática castellana (1492), había postulado, con irrefutables alcances ideológicos, el concepto de una lengua "imperial" necesaria para la expansión de España; prefiero concentrarme en la brillante idea de que hay una zona de la lengua inglesa que puede "superponerse" al "cansado español" de la realidad gaucha. $\mathrm{Al}$ asociar la lengua, sea el inglés o el español, con una realidad específica, la de los cowboys o la de los gauchos, Borges plantea la inevitable relación entre realidad cotidiana y representación verbal. Por más que este tema sea motivo de sesudas y aún irresueltas polémicas sobre filosofía del lenguaje, parece imposible rechazar la parcial verdad que contiene la afirmación del escritor, pues, en efecto, es más probable que una obra pueda traducirse a otra lengua si la realidad que ambas intentan representar tiene aspectos comunes, en este caso la vida rústica del gaucho y la del cowboy. Por ello Borges distingue con tino, y a la vez con sorna, que la traducción francesa, en cuya cultura no hay algo semejante a los gauchos, en gran medida ha convertido a éstos en meros peones agrícolas, refutando así su per-

33 J. L. Borges, "Don Segundo Sombra en inglés", en Borges: obras, reseñas y traducciones inéditas, ed. cit., p. 205. (Originalmente en Revista Multicolor de los Sábados, 11 de agosto de 1934, núm. 53.) 
tenencia a la vida ecuestre; por cierto que en este juicio percibo ecos del exacerbado criollismo borgeano de la década de 1920, cuando con encono atribuía la expansión de las labores agrícolas en Argentina, impropias del gaucho, al flujo de inmigrantes durante la segunda mitad del siglo XIX.

Ahora bien, de ningún modo lleva Borges su idea de la probable superposición entre dos lenguas al extremo de creer que una pueda "superponerse" a otra de manera absoluta. Él es siempre muy consciente de que si bien dos culturas pueden compartir realidades semejantes, eso no implica que logren borrarse sus diferencias verbales. Por ello al comparar en otro momento la estructura de varias lenguas, señala que cada idioma tiene formas de expresión específicas que imposibilitan su traducción a otro registro: "Así, en inglés, o en alemán, o en francés actual no hay manera de decir estaba solita, y en español no cabe decir to laugh it off o to explain away..."34.

En cuanto a las habilidades individuales del traductor de la versión inglesa de Don Segundo Sombra, quienquiera que éste haya sido ${ }^{35}$, Borges indica que una de sus virtudes es haber depurado el texto de Güiraldes de ciertos excesos estilísticos:

Hay más. Es dable observar en las páginas de Güiraldes, ante todo al principio de la novela, algunas pocas vanidades de estilo, propias de la hora "ultraísta" en que las escribió. La versión de Waldo Frank las ha eliminado. ¿Esto querrá decir que el gusto personal del traductor es más puro que el de Güiraldes? No sé; prefiero sospechar que es harto más fácil renunciar a vanidades ajenas que a vanidades propias ${ }^{36}$.

En otro escrito, y en un contexto muy distinto, Borges señaló uno de los problemas más comunes del traductor. Ante la

${ }^{34}$ J. L. Borges, con la colaboración de Betina Edelberg, Leopoldo Lugones (1965), en Obras completas en colaboración, $5^{\mathrm{a}}$ ed., Emecé, Barcelona, 1997, p. 506.

${ }^{35}$ La autoría de la traducción es un tanto confusa. Al inicio de su comentario, Borges dice que él y Adelina del Carril han revisado las pruebas de imprenta de esa inminente edición al inglés de Don Segundo Sombra, trabajada, añade, por Waldo Frank a partir de un borrador elaborado por Federico de Onís; sin embargo, la ficha bibliográfica del libro (Don Segundo Sombra, shadows on the Pampas, Farrar \& Rinehart, New York, 1935) atribuye la traducción a la esposa de este último, Harriet de Onís, y sólo reconoce a Frank el prólogo.

36 “Don Segundo Sombra en inglés", p. 205. 
declarada autosatisfacción de Lugones por sus traducciones de Homero, preparadas en versos alejandrinos, Borges comenta: "Acaso le parecieron buenas porque en cada palabra seguía oyendo el texto original; tal ilusión es frecuente en los traductores, y casi inevitable. Esta iluminación indirecta no alcanza al lector, que no ve sino el resultado último del trabajo" 37.

Sospecho que esta imborrable frontera entre la versión traducida y el original se ahonda cuando quien traduce no es ajeno al texto sino su creador, como sucedió con Borges en sus funciones de traductor al inglés de varios libros suyos, labor que emprendió en colaboración con Norman Thomas di Giovanni. Sobre los resultados de este trabajo conjunto, Emir Rodríguez Monegal emite un juicio contundente:

El conocimiento que Borges tenía del inglés era indiscutible: desde su infancia lo había utilizado como un nativo, e incluso mejor que eso, porque además lo estudió como si se tratara de un idioma extranjero. También era muy amplio su conocimiento de la literatura inglesa y norteamericana. Pero aun así, eso no le convertía en un escritor en inglés, especialmente si se entiende como tal alguien capaz de escribir con la libertad, la inventiva, la sensibilidad para las palabras, que caracterizaban a Borges como escritor en español. Para decirlo de otra manera, Borges, como traductor de sus propios textos, pasaba a ser anticuado, artificioso. Su manejo victoriano y libresco del idioma inglés suponía una limitación frente al español auténticamente creativo del original ${ }^{38}$.

En cierto sentido, quizá sea parcialmente válida la evaluación global de Rodríguez Monegal sobre esas traducciones al inglés que recibieron la contribución del escritor. Por ejemplo, aunque con una actitud benévola, Di Giovanni señala en cuanto a la calidad del inglés de Borges: "Aparte de sus características un tanto británicas y pasadas de moda, que yo afectuosamente llamo eduardianas, y que no son realmente importantes, a veces me desconcierta verlo dudar sobre si deberíamos utilizar una palabra como direction, que él no puede creer que sea una palabra del lenguaje ordinario"39. Pero, por otra parte, tamp. 490 .

37 J. L. Borges, con la colab. de B. EdelBerg, Leopoldo Lugones, ed. cit.,

38 Borges: una biografía literaria, F.C.E., México, 1987, p. 415.

39 Norman Thomas di Giovanni, "Trabajando con Borges", en Asedio a Jorge Luis Borges, ed. Joaquín Marco, Ultramar, Barcelona, 1982, pp. 203-204. 
bién pienso que es excesivo pedir que las traducciones al inglés hechas por Borges tengan la misma calidad del original en español, pues considero que, independientemente de quién sea el traductor, resulta imposible que una obra alcance el mismo grado de creatividad verbal en dos idiomas distintos. Por ello no me interesa emitir un juicio sumario sobre esas traducciones (para lo cual tampoco estoy capacitado), sino más bien examinar los comentarios de Di Giovanni sobre el proceso seguido por él y Borges para prepararlas; creo que de esta manera se podrá entender mejor cuál es el concepto de traducción construido por el escritor argentino.

Di Giovanni disfrutó de un lujo excepcional para un traductor: vivir la extraordinaria experiencia de trasladar junto con Borges textos de éste del español al inglés ${ }^{40}$. Al describir el método seguido por ambos, recuerda que primero él preparaba un borrador que sometía al juicio de Borges. Después, trabajaba a solas con ese borrador corregido por ambos, para darle forma final: "Cualquier referencia al texto español es generalmente para comprobar el ritmo o el énfasis. Mi obsesión ahora es casi exclusivamente el tono, la tensión o el estilo. Me preocupa por encima de todo el juego de tiempo o efectos. Estos no son problemas de traducción, son problemas de escritura" 41 . Sin duda, esta última frase de Giovanni, donde califica las dificultades surgidas durante esa etapa como problemas de escritura y no de traducción, se benefició de sus diálogos con Borges, quien en concordancia con Swinburne le recomendaba que se olvidara del original y fuera libre.

La última etapa de esas traducciones al alimón consistía en la lectura por Borges y Giovanni del texto corregido por éste:

Para nosotros, el escrito no tiene ya más que una forma. Llegado este punto nuestro único objetivo es conseguir que el texto se lea

${ }^{40}$ Una experiencia contemporánea paralela es la de SuZAnne JiLl Levine, en especial en sus traducciones al alimón con el escritor cubano Guillermo Cabrera Infante, cuyas versiones en inglés pueden ser incluso más extensas que el original, ya que ambos buscan soluciones adecuadas para cada caso particular. Levine, quien no ha traducido a Borges, ha dejado testimonio de esta fascinante práctica en su libro Escriba subversiva: una poética de la traducción (trad. Rubén Gallo, en colab. con la autora, F.C.E., México, 1998), en el cual abundan las menciones a la concepción borgeana de la traducción, que coincide casi puntualmente con la que ella ejerce en el ámbito profesional.

41 N. T. Di Giovanni, "Trabajando con Borges", p. 202. 
como si hubiera sido escrito en inglés. Hacemos pequeños ajustes, cambiamos una palabra aquí y allí, a veces modificamos una frase. De vez en cuando Borges añade una frase o un trozo de diálogo o hace una corrección que no se le ocurrió cuando escribió el original español. Por lo general traducimos este material del inglés al español para insertarlo en el texto original si aún no está publicado. Si el trabajo ya está impreso, proporcionamos al editor una lista de cambios para futuras ediciones ${ }^{42}$.

De este modo, uno de los sorprendentes resultados colaterales de sus traducciones es que pueden eventualmente enriquecer los textos originales. En cuanto a la orientación final que asumen los cambios introducidos en el texto original, ésta deriva, sin duda, de que Borges y Di Giovanni tienen presente el skopos de su traducción, pues como dice el último: "Hacemos estos cambios conscientes de que el lector para el que Borges escribe y aquel para el que traducimos son, por supuesto, personas completamente distintas" 43 . Para ejemplificar este proceso, Di Giovanni explica con detalle cómo prepararon ambos la traducción del relato breve titulado "Pedro Salvadores", que incluso fue publicado primero en inglés; ahí se percibe cómo ambos "coautores" (creo que ése es el nombre apropiado ${ }^{44}$ ) lograron superar las dificultades que implicaba el original, cuya abundancia de alusiones a la historia argentina resultaría difícil de comprender para los lectores anglosajones.

Por cierto que el tema del registro dialectal específico en el que debe codificarse una traducción no recibió gran atención por parte de Borges. Consciente de la diversidad de posibilidades que ofrece el español de ambos lados del Atlántico,

42 Loc. cit.

43 Ibid., p. 204.

${ }^{44}$ La página legal que consigna los derechos de autor de las obras de Borges traducidas al inglés por él y Di Giovanni (The Aleph and other stories, 1933-1969, Dutton, New York, 1970), reconoce la coautoría del último, por lo cual cualquier reproducción posterior que se quiera hacer del texto, o cualquier modificación, tiene que contar con su visto bueno; esto resulta inusual dentro de las prácticas comunes de las editoriales, ya que el traductor suele recibir un pago único por su labor, pero los derechos autorales son patrimonio exclusivo del autor, así como los de edición pertenecen al impresor. En más de un sentido esta labor conjunta es singular, pues, para complicar las cosas, hay que decir que la página legal reconoce derechos de coautoría en inglés no sólo a Di Giovanni, sino también a Adolfo Bioy Casares, de cuya participación no tengo noticias exactas. 
propugnó por el uso de una lengua que podríamos llamar panhispánica, o sea, aquélla que se puede comprender en cualquier dialecto del español:

Para nosotros la traducción al español hecha en la Argentina tiene la ventaja de que está hecha en un español que es el nuestro y no un español de España. Pero creo que se comete un error cuando se insiste en las palabras vernáculas. Yo mismo lo he cometido. Creo que un idioma de una extensión tan vasta como el español, es una ventaja y hay que insistir en lo que es universal y no local. Hay una tendencia en todas partes, sin embargo, a acentuar las diferencias cuando lo que habría que acentuar son las afinidades. Claro que como el Diccionario de la Academia lo que quiere es publicar cada año un volumen más abultado, acepta una cantidad enorme de palabras vernáculas. La Academia Argentina de Letras manda entonces largas listas de, por ejemplo, nombres de yuyos de Catamarca para que sean aceptadas y abulten el Diccionario ${ }^{45}$.

Se trata de una posición típica de su madurez como escritor, cuando ha superado la postura de criollismo lingüístico exacerbado presente en sus textos de la década de 1920. Sin embargo, el contexto donde se presenta esta opinión no deja de ser falaz y paradójico. La falacia reside en su acusación de que el Diccionario de la Real Academia Española incluye una cantidad exorbitante de americanismos, cuando todos sabemos que sucede lo contrario. Lo paradójico es que al ensalzar esa lengua ideal que se centre en las afinidades y olvide las diferencias, él no predique con el ejemplo, ya que recurre a una palabra tan marcadamente regional como "yuyo", identificada en el DRAE como propia de Argentina, Chile y Uruguay. En última instancia, creo que habría que enfatizar algo que suelen olvidar los traductores inexpertos: sólo es posible llegar a ese registro verbal "panhispánico" mediante el conocimiento amplio de los dialectos que forman la lengua española; nadie será consciente de las particularidades de su dialecto mientras no perciba que en otros dialectos se acude a otras palabras.

Aunque no puedo analizar aquí algunas traducciones borgeanas de obras ajenas, menciono que en ellas también ejerce la misma virtualidad creativa, pues suele añadir énfasis y crear omisiones que imprimen al texto nuevo un sentido diferente,

${ }^{45}$ J. L. Borges, "El oficio de traducir", pp. 323-324. 
de acuerdo con una intencionalidad y un uso específicos, es decir a partir de un skopos distinto (un ejemplo elemental de esto es la traducción de "hat" no con la palabra neutra "sombrero" sino con la más bien porteña "chambergo", en la traducción del texto de Max Beerbohm que estudio enseguida). La propuesta que ahora deseo hacer va por otra línea; en efecto, creo que debe precisarse que se trata, necesariamente, de un proceso con dos vertientes complementarias pero diferenciadas: por un lado, a partir de su concepto de traducción recreativa, Borges imprime a sus versiones traducidas rasgos estilísticos diferentes, propios de un texto nuevo y dirigido a otras finalidades; por otro, resulta lógico suponer que el largo comercio con la práctica translatoria influya en la escritura de Borges. En este sentido, me atrevo a sugerir un camino para este todavía no suficientemente explorado tema.

Sé muy bien que el caso que quiero analizar es polémico, pues aparece en la Antología de la literatura fantástica, compilada por Borges, Bioy Casares y Silvina Ocampo en 1940 y cuyas traducciones no están firmadas. Sin embargo, a partir de ciertos rasgos estilísticos (entre otros, por ejemplo, que la frase del inglés "I daresay I am the only person who noticed the omision" [p. 164] es traducida con un verbo inicial muy borgeano: "Sospecho que soy la única persona que lo notó" [p. 24]), yo deduzco que Borges fue el traductor de "Enoch Soames", de Max Beerbohm ${ }^{46}$. Cuando aparece el personaje principal de este cuento, es descrito de la siguiente manera: "He was a stooping, shambling person, rather tall, very pale, with longish and brownish hair. He had a thin vague beard..." (p. 166), pasaje que se traslada como: "Era una persona encorvada, vacilante, más bien alta, muy pálida, de pelo algo largo y negro. Tenía una rala, imprecisa barba..." (p. 26). Poco después se completa esta imagen con un calificativo específico para el sujeto: "I decided that «dim» was the mot juste for him" (p. 166), que es traducido por: "Decidí que «impreciso" era el mot juste que le correspondía" (p. 26). Hay que notar que si bien, de acuerdo con el campo semántico que se use, "vague" puede asumir los sentidos de "vago", "indistinto", "borroso", "incierto" o "impreciso", mientras

${ }^{46}$ La versión en español está en la citada Antología de la literatura fantástica (1940), Sudamericana, Buenos Aires, 1967, pp. 24-54. La versión original en inglés se reprodujo en The incomparable Max. A collection of writings of Max Beerbohm, Dodd, Mead and Co., New York, 1962, pp. 164-197. 
que "dim" podría significar "débil", "turbio", "oscuro", "sombrío", "indistinto" o "confuso", el texto en español opta en ambos casos por "impreciso", aunque el adjetivo se refiere primero a la barba del personaje y después a toda su persona.

Más allá de estos datos puntuales, me interesa destacar la semejanza que existe entre la descripción del personaje en el cuento de Beerbohm, tanto en el original como en su traducción, y la manera como se describe a Herbert Ashe en el famosísimo "Tlön, Uqbar, Orbis Tertius"; en ambos textos, hay la intención de "desdibujar" al personaje. Si se considera que la publicación de la Antología de la literatura fantástica es totalmente paralela a la versión original de "Tlön, Uqbar, Orbis Tertius" (Sur, mayo de 1940), se podrá concluir que hay un rico proceso de doble influencia o "contaminación": el texto en inglés de Beerbohm enseña al autor argentino una técnica de "desdibujamiento" de los personajes que aplicará en sus creaciones individuales, a la vez que la versión en español de "Enoch Soames" asume la entonación y ciertos rasgos verbales de la escritura de Borges.

Volviendo al testimonio de Di Giovanni, creo que en él se aprecia que Borges asumió con verdadera alegría su labor conjunta; entre otras razones, tal vez porque de ese modo pudo superar frustradas experiencias juveniles, como cuando al realizar su bachillerato en Suiza intentó infructuosamente escribir en otras lenguas: "Compuse sonetos, bien mediocres por cierto, en francés y en inglés. Ahora, ya no osaría hacerlo. Tengo un sentido de la responsabilidad que no tenía entonces. Creo que puedo escribir textos tolerables, digamos, o perdonables, en español, pero no en otra lengua alguna. ¡Cometí la imprudencia de publicar dos o tres piezas en inglés y estoy arrepentido!" 47

En cierta medida, las labores relacionadas con la traducción pueden posibilitar el cumplimiento de un profundo anhelo expresado en la poesía borgeana: apropiarse de la mayor cantidad de lenguas del mundo. En efecto, Borges, ávido del manejo de cada uno de los registros verbales, no dejó nunca de soñar con la utopía de que hubiera una lengua que combinara todas las posibilidades; esto se percibe, por ejemplo, en el poema "Al idioma alemán", que si bien arranca con el enfático y realista verso "Mi destino es la lengua castellana" - donde el au-

${ }^{47}$ J. L. Borges apud Georges Charbonnier, op. cit., p. 13. 
tor delimita su ámbito lingüístico más apropiado-, al mismo tiempo postula el íntimo deseo de inventarse una herencia verbal germánica:

Mi destino es la lengua castellana, el bronce de Francisco de Quevedo, pero en la lenta noche caminada me exaltan otras músicas más íntimas.

Alguna me fue dada por la sangre -oh voz de Shakespeare y de la Escritura-, otras por el azar, que es dadivoso, pero a ti, dulce lengua de Alemania, te he elegido y buscado, solitario ${ }^{48}$.

Para subsanar esta deficiencia, se dedicó con ahínco al estudio de la lengua y la literatura alemanas; como hemos visto, este interés se extendió a las traducciones a ese idioma, en particular las de Las 1001 noches (las versiones de Weil, Henning, Greve y Littmann), obra sobre la cual, por cierto, dijo con mucha razón que había adquirido más resonancia cultural en el mundo occidental que en el árabe. Después de su ya citado rechazo a la versión de Littmann, Borges arriesga una propuesta que no dudo en calificar como maravillosamente alucinante; dice que en el libro árabe hay prodigios que le gustaría ver repensados en alemán, y puesto que la cultura germánica posee una fuerte literatura fantástica, él imagina una traducción muy especial de Las 1001 noches: "El azar ha jugado a las simetrías, al contraste, a la digresión. ¿Qué no haría un hombre, un Kafka, que organizara y acentuara esos juegos, que los rehiciera según la deformación alemana, según la Umheimlichkeit de Alemania?" 49 Ojalá

48 “Al idioma alemán”, El oro de los tigres, en Obras completas, ed. cit., t. 2, p. 492. Su anhelo de posesión natural de la lengua inglesa es mucho más conocido, pues como confesó en 1970 en su mítico texto autobiográfico: "Mis tardes ahora las dedico por lo general a un proyecto de largo alcance que he querido llevar a cabo desde hace mucho: durante casi los últimos tres años, he tenido la suerte de tener a mi traductor [Norman Thomas di Giovanni] a mi lado, y juntos estamos sacando unos diez o doce volúmenes de mi obra en inglés, un idioma que soy indigno de manejar, un idioma que a menudo deseo hubiera sido mío por derecho de nacimiento" ( $\mathrm{J}$. L. Borges, Un ensayo autobiográfico [escrito originalmente en inglés en colaboración con N. T. di Giovanni], pról. y trad. Aníbal González, epílogo María Kodama, Galaxia Gutenberg-Círculo de Lectores-Emecé, Barcelona, 1999, p. 97; las cursivas son mías).

49 "Los traductores de las 1001 noches", p. 412. 
alguien se aventurara a construir esa compleja versión kafkiana de Las 1001 noches.

Si no me equivoco, a la luz de las ideas hasta aquí analizadas podría empezar a entenderse mejor una difundida anécdota de Borges, quien en diversas circunstancias afirmó que había leído primero el Quijote en inglés y que cuando leyó la versión original en español, ésta le pareció inferior a su traducción inglesa. Quienes repiten esta anécdota sin dudar de su veracidad, se olvidan de la ironía típica del autor, ya que quizá éste pudo haber querido reelaborar la broma, cierta o falsa, que se le adjudica a Byron, quien dijo que había leído a Shakespeare primero en italiano.

Al margen de esta probabilidad, hay que recordar que la novela de Cervantes fue usada por Borges en múltiples ocasiones y con muy variados propósitos, por lo que quiero referirme a uno que se relaciona con el tema de mi exposición. Para ello resumiré un ensayo de 1930 titulado "La supersticiosa ética del lector", donde el autor hace una aguda crítica al peculiar concepto de estilo que para entonces se había impuesto y a la importancia que se le asignaba al valorar una obra. Ahí, Borges fustiga a quienes entienden por estilo las "habilidades aparentes del escritor: sus comparaciones, su acústica, los episodios de su puntuación y de su sintaxis", pues "sólo buscan tecniquerías que les comunicarán si lo escrito tiene el derecho o no de agradarles" 50 . Añade que debido a esta creencia, nadie se atrevería a admitir la ausencia de "estilo" en los libros que le agradan, sobre todo si éstos son antiguos.

Pues bien, con esa lógica de la negatividad tan suya, Borges recurre precisamente al Quijote, la obra máxima del canon literario en lengua española, para derruir esa "supersticiosa ética del lector" que privilegia el estilo. Así, afirma que para explicar la permanencia de la novela de Cervantes entre sus lectores, la crítica española le "imputa" - el verbo es suyo- misteriosos valores de estilo; pero según su juicio, avalado por dos voces autorizadas en la Argentina de esa época, Paul Groussac y Leopoldo Lugones, basta con revisar algunos de sus párrafos para concluir que Cervantes no era un estilista, por lo menos en la acepción moderna del término, a la cual Borges califica como "acústico-decorativa"; así, pese al supuesto estilo deficiente del escritor español, denomina-

50 J. L. Borges, "La supersticiosa ética del lector" (1930), en Discusión, M. Gleizer Editor, Buenos Aires, 1932, p. 43. 
do incluso despectivamente como "prosa de sobremesa", Borges concluye que Cervantes es eficacísimo.

Borges va todavía más lejos en sus reflexiones, pues dice que en literatura la pretendida página perfecta, que simula ser invulnerable e indestructible, resulta la más precaria de todas, ya que ninguna de sus palabras puede ser alterada sin causar un daño irremediable al texto. En cambio, “...la página que tiene vocación de inmortalidad, puede atravesar el fuego inquisitorial de las enemistades, de las erratas, de las versiones aproximativas, de las distraídas lecturas, de las incomprensiones, sin dejar el alma en la prueba"51. ¿Qué mayor testimonio de esto que el inmortal texto de Cervantes!, concluye exultante Borges, quien asegura que mientras no se puede variar ninguna línea de las "perpetradas” por Góngora, “...el Quijote gana póstumas batallas contra sus traductores y sobrevive a toda versión. Heine, que nunca lo escuchó en español, lo pudo celebrar para siempre" 52 . En síntesis, para Borges la novela de Cervantes sobrevive cada vez que se la traduce porque es más grandiosa que cualquier posible tergiversación de su texto; es decir en todas las lenguas a las que ha sido vertido, se mantiene el "encanto esencial" del Quijote, como lo llamó en otra ocasión $^{53}$. La traducción pues parecería ser la prueba última e involuntaria a la que debe someterse una obra para demostrar su carácter clásico; a partir de estas reflexiones borgeanas, sería posible enunciar una nueva y sucinta definición de clásico: Clásico es aquel libro que puede ser leido como una gran obra en cualquier lengua a la que se traduzca.

No puedo dejar de mencionar que el ejemplo de Cervantes fue retomado por el autor muchos años después para construir una imagen dicotómica de la traducción poco convincente y que, en cierta medida, contradice algunas de las ideas hasta aquí expuestas, ya que se sugiere que mientras el traductor de poesía necesita recrear el texto original, no sucede lo mismo con el de prosa:

51 Ibid., pp. 47-48.

52 Ibid., p. 48.

53 "Juzgado por los preceptos de la retórica, no hay estilo más deficiente que el de Cervantes. Abunda en repeticiones, en languideces, en hiatos, en errores de construcción, en ociosos y perjudiciales epítetos, en cambio de propósito. A todos ellos los anula o atempera cierto encanto esencial” ( J. L. Borges, "Nota preliminar" a M. DE Cervantes, Novelas ejemplares, Emecé, Buenos Aires, 1946, p. 10). 
La traducción de poesía, en el caso de Fitzgerald o en el Omar Khayyam, por ejemplo, es posible porque se puede recrear la obra, tomar el texto como pretexto. Otra forma de traducción creo que es imposible... La prueba de que la prosa sí puede traducirse está en el hecho de que todo el mundo está de acuerdo en que el Quijote es una gran novela y, sin embargo, como lo hizo notar Groussac, los mayores elogios han sido hechos por personas que leyeron esa obra traducida. También todos estamos de acuerdo en que Tolstoi y Dickens fueron grandes novelistas y no todos sabemos inglés y casi nadie sabe ruso ${ }^{54}$.

Al margen de que esta cita borgeana fue emitida en el impreciso contexto oral de una encuesta sobre el oficio del traductor, hay que intentar identificar su sentido concreto. Para ello acudo, imitando el estilo argumentativo de Borges, a un contraejemplo que refuta su afirmación de que la prosa sí puede traducirse: pese a su forma prosística, la obra de Joyce resulta "intraducible", en cuanto que los juegos verbales del autor irlandés se pierden al pasar del inglés a otro idioma. Como sabemos, Borges ensayó traducir la última página del Ulises ${ }^{55}$, en un ejercicio en el que recurrió a cambios y omisiones cuyo significado global indica Waisman: "These kinds of omissions represent a recontextualizing that makes the fragment function better as an autonomous piece, allowing it to exist on its own, as a (co-)creation of the translator's"56. Luego de su temprano intento por traducir a Joyce, Borges reforzó su creencia en el carácter "intraducible" de este escritor; así se percibe, por ejemplo, en una nota donde comenta la versión del Ulises preparada por Salas Subirats ${ }^{57}$.

54 J. L. Borges, "El oficio de traducir", pp. 321-322.

55 J. L. Borges, "La última hoja de Ulises", Proa, enero de 1925, núm. 6, 8-9.

56 Sergio Gabriel Waisman, "Borges reads Joyce. The role of translation in the creation of texts", Variaciones Borges, 2000, núm. 9, p. 66. Al analizar la traducción de Borges, Waisman acude, entre otros textos, al ensayo "Fragmento sobre Joyce" (Sur, 1941), que en su primera parte contiene una versión abreviada de lo que después sería "Funes el memorioso"; el crítico plantea la interesante hipótesis de que mediante este cuento, cuyo personaje poseedor de una memoria absoluta es el lector ideal de Joyce, Borges responde, de forma sintética, a la misma inquietud literaria que sustenta la obra del irlandés: cómo capturar cada momento, emoción y pensamiento de un día.

${ }^{57}$ Jorge Schwartz ("Borges y la primera hoja de Ulysses", RevIb, 100/101, 1977, 721-728) compara de forma breve pero muy sugerente las versiones de Borges y de Salas Subirats, luego de lo cual reproduce el texto en español de la última página de Joyce publicado por el primero en la revista Proa. 
"A priori, una versión cabal del Ulises me parece imposible" 58 .

En suma, conjeturo que al enunciar la ineficiente dicotomía entre traducción de poesía y traducción de prosa, Borges estaba pensando más bien en el particular modo de escritura usado por cada texto; por ello recuerdo ahora su recelo absoluto contra la literatura que cifra casi todo su prestigio en la construcción de juegos verbales extremos, postura que le impidió aceptar sin reservas la obra de Góngora: "Los idiomas del hombre son tradiciones que entrañan algo de fatal. Los experimentos individuales son, de hecho, mínimos, salvo cuando el innovador se resigna a labrar un espécimen de museo, un juego destinado a la discusión de los historiadores de la literatura o al mero escándalo, como el Finnegans Wake o las Soledades"59. En el verbo "resignar" percibo las prevenciones de Borges contra esos experimentos verbales que, pese al enorme esfuerzo de creación que implicaron, no obtienen una amplia respuesta de lectura; de hecho, en ambos casos se trata de obras "intraducibles" (o que por lo menos pierden sus excelsos recursos verbales en el intento de trasladarlas de una lengua a otra); pienso que, en última instancia, la concepción que expresa sus inclinaciones más profundas es que cualquier traducción, trátese de poesía o prosa, parte siempre de una reelaboración del texto en donde las capacidades inventivas del traductor se ponen a prueba.

Asimismo, además de expresar su firme convicción sobre la noble tarea del traductor, la postura general de Borges se puede interpretar como una respuesta indirecta a José Ortega y Gasset, quien, dentro del mismo campo cultural, emitió opiniones muy distintas que Borges no pudo dejar de conocer. En efecto, entre mayo y junio de 1937, el ensayista español publicó en La Nación una serie de artículos en forma de diálogo bajo el título general de "Miseria y esplendor de la traducción", donde luego de preguntarse si traducir no es un afán utópico sin re-

58 J. L. Borges, "Nota sobre el Ulises en español", Los Anales de Buenos Aires, enero de 1946, núm. 1, p. 49. Del mismo modo, en otro lugar afirma, respecto de Ulises y Finnegans Wake: "Los libros que hemos enumerado son intraducibles" ( J. L. Borges, con la colab. de MARía Esther VÁzQuez, Introducción a la literatura inglesa, en Obras completas en colaboración, Emecé, Barcelona, 1995, p. 854).

59 "Prólogo" a El otro, el mismo, en Obras completas, ed. cit., t. 2, p. 235. 
medio, califica esa labor como una "modesta ocupación" y dice que "en el orden intelectual no cabe faena más humilde" 60 ; el contraste que él establece entre la escritura original y su traducción no podría ser más contundente:

Escribir bien consiste en hacer continuamente pequeñas erosiones a la gramática, al uso establecido, a la norma vigente de la lengua. Es un acto de rebeldía permanente contra el contorno social, una subversión. Escribir bien implica cierto radical denuedo. Ahora bien; el traductor suele ser un personaje apocado. Por timidez ha escogido tal ocupación, la mínima. Se encuentra ante el enorme aparato policíaco que son la gramática y el uso mostrenco. ¿Qué hará con el texto rebelde? ¿No es pedirle demasiado que lo sea él también y por cuenta ajena? Vencerá en él la pusilanimidad y en vez de contravenir los bandos gramaticales hará todo lo contrario: meterá al escritor traducido en la prisión del lenguaje normal, es decir, que le traicionará. Traduttore, traditore ${ }^{61}$.

El tenue "esplendor" al que alude su título se refiere casi exclusivamente a la función pragmática de las traducciones, a las cuales sólo de manera excepcional reconoce Ortega un valor estético (posibilidad latente cuando el autor traducido es contemporáneo del traductor). En fin, sin duda la postura de Ortega y Gasset es diametralmente opuesta a la asumida por el escritor argentino, lo cual comprueba una vez más la nula confluencia entre ellos ${ }^{62}$.

60 José Ortega y Gasset, "Miseria y esplendor de la traducción”, en Obras completas, Alianza-Revista de Occidente, Madrid, 1983, t. 5, pp. 434.

61 Loc. cit.

${ }^{62}$ Nunca fue un secreto la falta de simpatía borgeana por Ortega, aspecto que se percibe, entre otros elementos, en el seudónimo de Ortelli y Gasset con el que él y su amigo Carlos Mastronardi firman "A un meridiano encontrao en una fiambrera" (Martín Fierro, 10 de junio de 1927, núm. 42), donde para rechazar burlonamente el polémico editorial de la Gaceta Literaria de Madrid que afirmaba que la capital española debía ser el meridiano cultural de América, ellos construyen un texto irónico en lunfardo que resulta incomprensible fuera de ese ámbito cultural y lingüístico, ya que, en palabras de Mastronardi: "Para subrayar diferencias, [Borges y yo] recurrimos al más espeso y oscuro vocabulario lunfardo" (C. Mastronardi, Memorias de un provinciano, Eds. Culturales Argentinas, Buenos Aires, 1967, p. 197). Nicolás Helft (Jorge Luis Borges: bibliografía total, F.C.E., Buenos Aires, 1997, p. 283) acude a este testimonio para avalar la coautoría de Borges y Mastronardi respecto de esta nota, aunque José Luis Trenti Rocamora adjudica el seudónimo a Leopoldo Marechal, con base en una declaración de éste aparecida en el último número de Martín Fierro y dirigida a los "com- 
Supongo que a partir de lo expuesto, podrá entenderse mejor una frase de Borges que en primera instancia parece una mera boutade: "El original es infiel a la traducción"63; más que de infidelidad en sí, la frase alude al hecho potencial de que una traducción supere literariamente a su referente, pues el grado de creación verbal al que puede llegar no tiene límite; a eso es a lo que él llama "infidelidad creadora" en el siguiente pasaje sobre Mardrus, quien forma, junto con Galland y Burton, la trilogía de sus traductores favoritos de Las 1001 noches:

En general, cabe decir que Mardrus no traduce las palabras sino las representaciones del libro: libertad negada a los traductores, pero tolerada en los dibujantes... Sólo me consta que la "traducción" de Mardrus es la más legible de todas -después de la incomparable de Burton, que tampoco es veraz... Celebrar la fidelidad de Mardrus es omitir el alma de Mardrus, es no aludir siquiera a Mardrus. Su infidelidad, su infidelidad creadora y feliz, es lo que nos debe importar ${ }^{64}$.

pañeros" de la Gaceta Literaria: "Nadie tomó en serio vuestro meridiano y las contestaciones joco-serio-despectivas de Martín Fierro son una buena prueba de lo que digo; inventamos alegremente ese personaje absurdo que se llama Ortelli Gasset y que tanto estrago causó en vuestras filas" (L. Marechal apud J. L. TRENTI, Índice general y estudio de la revista "Martín Fierro" [1924-1927], Sociedad de Estudios Bibliográficos Argentinos, Buenos Aires, 1996, p. 43); el plural en primera persona usado por Marechal no me parece una prueba convincente para adjudicarle la autoría individual del texto; en este punto, coincido con CARLOS GARCía: "El más superfluo de los errores de Trenti es el que atribuye a Leopoldo Marechal la autoría de un texto satírico firmado «Ortelli y Gasset». Trenti basa su erróneo aserto en un giro de Marechal: «Inventamos alegremente ese personaje absurdo que se llama Ortelli y Gasset». Pero Marechal no refiere ese «inventamos» a sí mismo, sino, en sentido figurado, a «nosotros, los martinfierristas»" (El joven Borges, poeta [19191930], Corregidor, Buenos Aires, 2000, p. 199). Más allá de esto, es indudable que Borges nunca ocultó su antipatía por Ortega y Gasset, según se aprecia en esta confesión: "[Ortega y Gasset] No me causó ninguna impresión; hablé con él una sola vez, diez o quince minutos, y creo que nos aburrimos mutuamente. Yo le hablé de Cansinos Assens y él, por cortesía, para no decirme que no le gustaba, me dijo que no lo había leído nunca y esa fue toda la conversación. Además, lo conocí en lo de Victoria Ocampo, que tenía un modo de imponer a sus amigos que los hacía desagradables" ( J. L. Borges apud María Esther VÁzquez, Borges, sus días y su tiempo, Javier Vergara, Buenos Aires, 1999, p. 127).

63 "Sobre el Vathek de William Beckford", Otras inquisiciones, en Obras completas, ed. cit., t. 2, p. 109.

64 "Los traductores de las 1001 noches", pp. 409-410. Al final de su comentario, Borges ha afinado la expresión paralela que había usado en "El 
De este modo, no sólo se supera el criterio de "fidelidad" con el que suele juzgarse a las traducciones, sino que incluso se asignan a ésta valores negativos: entre más "fiel" sea una traducción, poseerá menos cualidades creativas; en síntesis, dentro del proceso de traducción, los verdaderos actos creativos sólo pueden ejercerse a partir de un fecundo sentido de traición al original. Desde esta perspectiva, en cuanto meros objetos verbales, no hay diferencias sustanciales entre un original y su traducción, aunque, como señala Borges en un ensayo de la década de 1960, el lector siempre está prejuiciado por el prestigio inherente a la obra original:

Es decir, la diferencia entre una traducción y el original no es una diferencia entre los textos mismos. Supongo que si no supiéramos cuál es el original y cuál la traducción, los podríamos juzgar con imparcialidad. Pero, desgraciadamente, no puede ser así. $\mathrm{Y}$, en consecuencia, el trabajo del traductor siempre lo suponemos inferior $-\mathrm{o}$, lo que es peor, lo sentimos inferior- aunque, verbalmente, la traducción puede ser tan buena como el texto ${ }^{65}$.

Ahí mismo, luego de recordar que en la Edad Media la traducción era considerada como un proceso recreativo motivado por la lectura de una obra, el escritor comenta que, a su parecer, la traducción de Les fleurs du mal al alemán (Blumen des Böse), supera el original de Baudelaire, pues si bien éste es un poeta superior a Stefan George, como traductor George fue un artesano mucho más hábil; no obstante este arriesgado comentario, finalmente acepta: "Pero esto, evidentemente, no le vale a Stefan George, pues las personas interesadas en Baudelaire - y a mí Baudelaire me ha interesado mucho- entienden

puntual Mardrus”, Revista Multicolor de los Sábados, 3 de febrero de 1934, p. 8: "Alabar la precisión de Mardrus es omitir el alma de Mardrus, es no aludir siquiera a Mardrus. Su imprecisión, su jubilosa imprecisión creadora, es lo que nos debe importar"; el título de ese ensayo remitía al generalizado juicio previo que había alabado la "puntualidad" de Mardrus, sobre todo por haber restituido a Las 1001 noches pasajes eliminados en las traducciones anteriores.

65 "La música de las palabras y la traducción”, en Arte poética, trad. Justo Navarro, pról. Pere Gimferrer, ed., notas y epílogo Calin-Andrei Mihailescu, Crítica, Barcelona, 2000, p. 83; en principio, este texto fue una conferencia pronunciada en inglés a fines de la década de 1960 en Harvard University. 
que las palabras proceden de Baudelaire"66; creo que, implícitamente, estas líneas marcan una diferencia entre las concepciones de Borges y de Vermeer: mientras éste considera que el traductor requiere siempre mayores capacidades verbales que quien crea libremente, aquél implica que el traductor recibe el impulso del texto original (es decir el apoyo de las palabras de otro).

En cuanto a las "infidelidades" inherentes a la traducción, es obvio que no todas implican un acto creativo. Quizá una anécdota que, además del apellido común, liga a Borges y a Juan Carlos Onetti Borges (escritor extraordinario que fue también traductor casi profesional durante varias etapas de su vida) sirva para iluminar este aspecto. Onetti dice haberse dedicado una época a "rastrear algunas de las infamias que se habían hecho al traducir obras del genial norteamericano"67, como él califica a Faulkner, a quien profesaba una profunda veneración. Al final de su nota, el escritor uruguayo menciona la famosísima traducción de Borges de Las palmeras salvajes ${ }^{68}$, pero lo hace de forma sesgada, pues en lugar de hablar de la versión borgeana completa, es decir de evaluarla en su totalidad ${ }^{69}$, de-

${ }^{66} \mathrm{Ibid} .$, p. 93.

67 "Incursiones en Faulkner", en Confesiones de un lector, Alfaguara, Madrid, 1995, p. 349.

68 William Faulkner, Las palmeras salvajes, trad. Jorge Luis Borges, Sudamericana, Buenos Aires, 1940. Quizá debido a un error tipográfico, la muy útil bibliografía de Nicolás Helft (Jorge Luis Borges: bibliografia completa) establece 1944 como fecha de esta traducción, la cual tuvo un éxito enorme; así, para 1956 llevaba ya cuatro reimpresiones, en parte porque fue el medio para que el escritor estadounidense, de quien Lino Novás Calvo había traducido Sanctuary (Espasa-Calpe, Madrid, 1934), fuera difundido tanto en Hispanoamérica como en España: "Esta versión se leerá mucho en España, así como el resto de las traducciones realizadas en Argentina durante el decenio de los años cuarenta. Hispanoamérica se convertirá, así pues, en mantenedora de la comunicación con Faulkner para los enclaustrados españoles de la posguerra" (María Elena Bravo, Faulkner en España. Perspectivas de la narrativa de posguerra, Península, Barcelona, 1985, p. 24). En su documentado libro Aproximación a una historia de la traducción en España (Cátedra, Madrid, 2000), José Francisco Ruiz Casanova enlista la nada deleznable presencia de Borges traductor en España a lo largo del siglo xx. En cuanto a la influencia de este escritor en Hispanoamérica, véase TANYA T. FAYEN, In search of the Latin American Faulkner, University Press of America, Lanham, 1995.

${ }^{69}$ Hay dos trabajos breves que comparan la traducción de Borges con el original en inglés: María Elena Bravo, "Borges traductor: el caso de The wild 
cide centrarse en un minúsculo mas significativo detalle de la última frase:

Y para terminar por ahora, recuerdo que en la traducción firmada por Borges de Palmeras salvajes, en la parte llamada El viejo, se dice al final que el penado alto, luego de escuchar las peripecias que el Mississippi le impuso a su compañero de prisión, resumió su opinión en una sola palabra: mujeres.

Muchas veces, cuando me cuentan alguno de esos pequeños disturbios aldeanos por una dulce señora o señorita, me he limitado a comentar la anécdota o chisme repitiendo: "Mujeres, dijo el penado alto".

Pero hoy, al documentarme muy severamente para escribir este artículo, descubro que la totalidad del comentario del penado alto fue:

- Women shit.

Con perdón de Borges $^{70}$.

Por mi parte, yo diría, con perdón de Onetti, que al sumar la versión traducida o "firmada" por Borges a la lista de las infamias cometidas contra Faulkner, el escritor uruguayo no es del todo justo. En efecto, aunque él presume de bien documentado, sus referencias bibliográficas no son precisas, pues la edición original de The wild palms, de 1939, en la que se basó la versión británica de la que tradujo Borges ${ }^{71}$, no contiene com-

palms, de William Faulkner”, Ínsula, 1985, núm. 462, 11-12, y más recientemente MARIAN B. LABRUM, "Las palmeras salvajes en traducción de Jorge Luis Borges: crítica y evaluación”, Livius. Revista de Estudios de Traducción (León), 1998, núm. 12, 85-93.

${ }^{70} \mathrm{~J}$. C. ONeTTI, op. cit., pp. 352-353.

${ }^{71}$ Mediante el auxilio de modernos recursos electrónicos, M. B. LABRUM comprueba que la traducción de Borges no se basó en el texto original de Faulkner publicado en Estados Unidos (Random House, New York, 1939) sino en su modificada edición británica (Chatto and Windus, London, 1939): "El uso de un ordenador para hacer la comparación del texto estadounidense con el texto británico, permitió determinar, de manera más sistemática y conclusiva, que el texto fuente que Borges utilizó para traducir al español era significativamente diferente de la novela original escrita por William Faulkner" (op. cit., p. 88). Ahora bien, luego de analizar los "errores" y "omisiones" de la traducción borgeana, Labrum llega a un tajante juicio: "La traducción de Borges no es completa ni precisa, como tiene fama de ser" (p. 92); comete así la injusticia de aplicar a la versión traducida un criterio de "fidelidad" que de ningún modo era el seguido por el escritor argentino. Más equilibrado y comprehensivo de las intenciones translatorias de Borges me parece este comentario: "Ahora bien, el Borges creador de un 
pleta la frase "Women shit"; esta última palabra ha sido sustituida, pudorosamente, por un guión largo y la " $t$ " final. Ignoro si el recato verbal provino en sus orígenes de Faulkner (hipótesis poco probable) o de algún editor quisquilloso, pero lo cierto es que si bien Borges eliminó completa la supuesta mala palabra, no puede adjudicársele la responsabilidad plena. Tan movedizas son las arenas de este campo que incluso algunas ediciones posteriores en inglés eliminaron totalmente la supuesta palabra indecorosa 72 .

Ahora bien, en su sentido positivo, creo que resulta conveniente preguntarse cuáles son para Borges los límites de esa "infidelidad creadora y feliz" que es en esencia la traducción. Para ubicar la respuesta a este interrogante, hay que realizar primero una necesaria pero breve digresión sobre algunas características generales de su escritura. Como sabemos, la tradicional división por géneros (cuento, poesía y ensayo) no resulta de ningún modo funcional en la obra de Borges. Así, la mezcla de procedimientos pertenecientes a uno u otro género impide a sus lectores memorizar con exactitud dónde se encuentra tal o cual pasaje; por ejemplo, una reflexión sobre las limitaciones de la lengua como instrumento de representación no siempre aparece en un ensayo, sino también en un texto con elementos narrativos, como sucede en "Funes el memorioso". Asimismo, quizá los receptores no nos hemos percatado de que algo semejante sucede con los temas de sus escritos, pues con frecuencia el título de un texto no remite directamente a su contenido.

Traigo a colación estos rasgos atípicos de la literatura de Borges porque el pasaje donde él expresa de forma implícita

estilo extraordinario no debe hacernos olvidar al Borges traductor profesional, y éste, no podía ser de otro modo, comete errores que, a pesar de sus críticas a la «literalidad»y al excesivo uso del diccionario, se deben a lo primero por falta de lo segundo. No es nuestra intención reseñarlos, sino indicar que, a pesar de ellos, sus versiones se leen como si fueran excepcionales" (Ana Gargatagli y Juan Gabriel López Guix, "Ficciones y teorías en la traducción: Jorge Luis Borges", Livius. Revista de Estudios de Traducción, 1992, núm. 1, p. 64). En Jorge Luis Borges y la traducción (tesis doctoral, Universidad Autónoma de Barcelona, 1994), A. GARGATAgLi desarrolla, en líneas generales, las ideas que había apuntado en este primer artículo en coautoría.

72 Por ejemplo, la edición de 1984 publicada por Random House en Nueva York simplemente termina: “《Women-!» the tall convict said”, lo cual demuestra que también en la lengua original se ha producido la eliminación que Onetti atribuye a Borges. 
hasta qué maravillosos y dilatados límites puede llegar la traducción, se encuentra en un ensayo cuyo título no anuncia este tema: "De las alegorías a las novelas". En este texto Borges aplica una de las lecciones derivadas de "El pudor de la historia", donde critica con ironía la necia actitud de la humanidad por buscar fechas simbólicas que marquen los hitos de la historia; en lugar de esas cumbres excelsas de acontecimientos militares o sociales con que suele definirse el rumbo de la historia, él propone algo más sutil: “...yo he sospechado que la historia, la verdadera historia, es más pudorosa y que sus fechas esenciales pueden ser, asimismo, durante largo tiempo, secretas"73. Pues bien, con el objeto de desvelar una de esas fechas secretas, en este caso de la sutil historia literaria, en "De las alegorías a las novelas" Borges intenta identificar cuándo nace el género novela:

El pasaje de alegoría a novela, de especies a individuos, de realismo a nominalismo, requirió algunos siglos, pero me atrevo a sugerir una fecha ideal. Aquel día de 1382 en que Geoffrey Chaucer, que tal vez no se creía nominalista, quiso traducir al inglés el verso de Boccacio "E con gli occulti ferri i Tradimenti" (Y con hierros ocultos las Traiciones), y lo repitió de este modo: "The smyler with the knyf under the cloke" (El que sonríe, con el cuchillo bajo la capa) ${ }^{74}$.

Antes de comentar este párrafo, quiero señalar que la frase final, "The smiler with the knife under the cloak", fue retomada por Julio Cortázar como título de uno de los textos de $L a$ vuelta al día en ochenta mundos, donde dice que en 1956, durante una estancia en la India, se acordó: “...de unas clases de literatura inglesa allá por la calle Charcas, en las que él [Borges] nos había mostrado cómo el verso de Geoffrey Chaucer era exactamente la metáfora criolla de «venirse con el cuchillo abajo'el poncho», y me ganó una ternura idiota"75. Cito aquí esta

73 "El pudor de la historia", Otras inquisiciones, en Obras completas, ed. cit., t. 2, p. 132 .

74 "De las alegorías a las novelas", Otras inquisiciones, en Obras completas, ed. cit., t. 2, p. 124. Naturalmente, Borges escribe la última palabra con la grafía "cloke" del inglés antiguo, que se encuentra en los diccionarios actuales como "cloak".

75 "The smiler with the knife under the cloak", La vuelta al dia en ochenta mundos, Siglo XXI, México, 1967, p. 41. 
dulce anécdota cortazariana, en la que Borges asimila a Chaucer a lo criollo, porque creo que es sintomática de esa permanente intención suya de traducir todo no sólo lingüística sino culturalmente (aunque habría que pensar también en que la frase alude a un acto de traición que parece impropio de la mitología de cuchilleros criollos elaborada por Borges, quien sostenía que las muertes se cometían siempre de frente, en el disfrute pleno del valor y del coraje).

En fin, volviendo a la cita de Borges, lo esencial es que él sostiene que al trasladar la frase de Boccaccio del italiano al inglés, Chaucer, en un acto de creación extrema, pasó de lo general a lo particular, de la especie al individuo, con lo que posibilitó, añado yo, el desarrollo de lo que denominamos el héroe moderno, personaje necesario para el ahora múltiple género de la novela. No me atañe discutir aquí los alcances de esta afirmación, que el autor no argumenta con mayor amplitud. Para mis propósitos, lo fundamental es destacar con asombro que Borges propone que el nacimiento de la novela reside no en lo que se llamaría, al modo tradicional, un acto de creación pura, sino en una labor que durante siglos ha sido considerada como subsidiaria: la traducción.

En síntesis, de acuerdo con el estilo ensayístico de Borges, que suele buscar la esencia de la literatura donde otros sólo verían intersticios o minucias verbales, él derruye de una vez y para siempre la peregrina idea de que la traducción es secundaria, ya que si un mero acto de traducción, es decir de "infidelidad creadora y feliz", dio origen a un género tan vasto en el mundo occidental moderno como ha sido la novela, entonces nunca más deberá pensarse en la traducción como una práctica secundaria y hasta cierto punto prescindible.

Rafael Olea Franco

El Colegio de México 